\title{
WALORYZACJA PRZESTRZENI MIESZKANIOWEJ ZMODYFIKOWANA METODĄ AUDYTU MIEJSKIEGO
}

\author{
Dr hab. Lidia Groeger, prof. UŁ - Uniwersytet Łódzki \\ Instytut Zagospodarowania Środowiska i Polityki Przestrzennej \\ Collegium Geographicum \\ ul. Kopcińskiego 31, 90-142 Łódź \\ e-mail: lidia.groeger@geo.uni.lodz.pl \\ https://orcid.org/0000-0003-0369-109X \\ Mgr inż. Kamil Lasek \\ - Pracownia Analiz Środowiskowych EkoPerfekt Spółka z o.o. \\ ul. M. Konopnickiej 4, 97-300 Piotrków Trybunalski \\ e-mail: k.c.lasek@gmail.com \\ https://orcid.org/0000-0002-4738-3825
}

ZARYS TREŚCI: Jakość przestrzeni mieszkaniowej nabiera współcześnie coraz większego znaczenia w powszechnym odczuciu społecznym. Towarzyszy temu intensywny rozwój badań nad jakością życia mieszkańców w zakresie zagospodarowania przestrzennego oraz społecznego postrzegania miejsca zamieszkania. Artykuł poświęcony został zastosowaniu metody audytu miejskiego do waloryzacji publicznej przestrzeni mieszkaniowej. Celem opracowania jest stworzenie wykazu modyfikacji ukierunkowujących oraz silniej dostosowujących wspomnianą metodę do badania struktur osiedlowych. Zasadnicza część zaproponowanych zmian opracowana została na podstawie badania waloryzacyjnego oraz ankietowego wykonanego na osiedlu Wyzwolenia w Piotrkowie Trybunalskim przy wykorzystaniu metody audytu miejskiego. Przeprowadzone analizy pozwoliły sformułować modyfikacje w obrębie skali ocen oraz katalogu cech poddawanych ocenie w ramach realizacji audytu. Uznano, iż charakter tych zmian odpowiada skali większości osiedli mieszkaniowych oraz pozwoli na precyzyjniejsze planowanie działań interwencyjnych w ramach polityki miejskiej. Przeprowadzone badania pozwoliły również wskazać na istotną rolę badania społecznego ${ }^{1}$ jako uzupełniania dla wyników audytu sporządzonego dla podsystemu urbanistycznego. Jest ono 
zarazem formą uwzględnienia partycypacji społecznej w kształtowaniu wytycznych do gospodarowania przestrzenią mieszkaniową. Należy też zaznaczyć, iż w opracowaniu skupiono się na badaniu publicznej przestrzeni mieszkaniowej, jednak w zależności od założonych celów waloryzacja może zostać uzupełniona o ocenę prywatnej przestrzeni mieszkaniowej jako równoważnej składowej ogólnej kategorii badanej przestrzeni.

SŁOWA KLUCZOWE: waloryzacja obszarów mieszkaniowych, audyt miejski, osiedle mieszkaniowe, publiczna przestrzeń mieszkaniowa.

\title{
VALORIZATION HOUSING SPACE MODIFIED BY URBAN AUDIT
}

\begin{abstract}
The quality of the housing space is now becoming more important in general social impairment. This is accompanied by an intensive development of studies on the quality of life of residents in the field of spatial development and public perception of the place of residence. The valorisation of the housing space occupies a special position in the area of research on housing. The article concerns the application of the Municipal Audit method for the valorisation of public housing space. The aim of the study is to propose a modification of that method in order to better adapt this method to the assessment of residential structures. The advantage of the audit is its simplicity in the procedural and analytical layer (uncomplicated scoring, the possibility of calculating average values, results visualized spatially on maps), which makes it possible to be widely used, especially by local governments, also in the context of low costs of carrying out such research. In the initial parts of the work brought closer to issues of terminology and the theoretical basis of the valorization in general by referring to its criteria and types. Issues of methodological structure and stages of audit development on foreign and Polish development were also submitted. Further part of the work was devoted to the proposed modifications of the Municipal Audit as the methods of valorisation of public housing space, in particular housing estate. The most significant changes have been made within the directory variable and the scale of assessments. The extension of the list of features subjected to assessment has been dictated by their unambiguous belonging to the overriding category of public housing space and the scale of settlement units, which allows thorough valorization tests due to the possibility of distinguishing relatively small urban units in which analyzes are carried out. It was recognized that the legitimacy of the introduction of a wider scale of assessment is also justified in the possibility of formulating precise schedules of intervention and recovery plans implemented under the settlement urban policy. The essential part of these modifications was formulated on the basis of an valorisation and a questionnaire examination carried out on the Wyzwolenia Estate in Piotrków Trybunalski using the present method. The conducted research also allowed to indicate the important role of social research as a supplement to the results of the audit prepared for the urban subsystem. It is also a form of taking into account social participation in the development of guidelines for the management of housing space. It should also be noted that the study focuses on the study of public housing space, however, depending on the assumed goals, the valorization may be supplemented with the assessment of private housing space as an equivalent component of the general category of the studied space.
\end{abstract}

KEYWORDS: valorization of residential area, Urban Audit, housing estate, public residential space. 


\subsection{Wprowadzenie}

Mieszkanie, rozumiane jako miejsce stałego pobytu ludzi, zajmuje szczególną pozycję w hierarchii potrzeb człowieka. Godne warunki mieszkaniowe nabierają obecnie coraz większego znaczenia w powszechnym odczuciu społecznym (Sikora-Fernandez 2018). Znajduje to wyraz w intensywnie rozwijającym się współcześnie nurcie badań nad jakością życia mieszkańców w zakresie zagospodarowania przestrzennego miejsca zamieszkania oraz społecznego postrzegania i wartościowania ${ }^{1}$ przestrzeni mieszkaniowej (Groeger 2018). W tym kontekście pojęciem bliskim znaczeniowo wartościowaniu jest waloryzacja. W ujęciu możliwie ogólnym ma ona na celu ocenę wartości przestrzeni geograficznej z punktu widzenia realizacji określonych potrzeb człowieka (Kurek, Mika i in. 2008). Wyróżnić można dwie zasadnicze grupy metod oceny przestrzeni: bezwzględne (absolutne) oraz względne (porównawcze) (Janiszek, Majorek 2017). Różnice znaczeniowe między wskazanymi pojęciami można z kolei sprowadzić do stwierdzenia, iż waloryzacja odnosi się bardziej do wiedzy, natomiast wartościowanie do odczuć (Włodarczyk 2014).

W szerokim rozumieniu za kryteria wartościowania/waloryzacji terytorium (przestrzeni) można uznać cechy ekonomiczne, techniczno-technologiczne, społeczne oraz polityczne (Szul 1991). W ramach nauk socjologicznych w relacji jednostki z przestrzenią można z kolei wyróżnić wartości instrumentalne, sytuacyjne i egzystencjalne (Wallis 1990). Należy jednak mieć na uwadze, iż kryteria oceny przestrzeni są kształtowane przede wszystkim w odniesieniu do odczuwanych potrzeb (Wallis 1990).

Zagadnienie waloryzacji przestrzeni miejskiej zarówno pod względem technik, metod badawczych jak również źródeł (także baz) danych mogących stanowić podstawę do przeprowadzenia oceny takiej przestrzeni szeroko omówiła Cieślak (2012) $)^{2}$.

${ }^{1} \mathrm{~W}$ nurcie badań z zakresu geografii społeczno-ekonomicznej wartościowanie środowiska oznacza ocenę środowiska człowieka z punktu widzenia zaspokojenia jego potrzeb (Runge A., Runge J. 2008).

${ }^{2}$ Metody waloryzacji zostały zgrupowane według charakteru ocenianej przestrzeni. Wyróżniono metody waloryzacji fizjograficznej, do których włączono metodę stałych kategorii, zbiorczą kwalifikację ekofizjograficzną terenu oraz uproszczoną waloryzację geokompleksów. W ramach waloryzacji krajobrazów kulturowych przedstawiono metodę JARK-WAK Bogdanowskiego, metodę DCP w badaniu ciągłości przestrzeni oraz metodę wartościowania krajobrazu a pomocą kryterium linii prostej Janeckiego. Przegląd metod socjologicznej waloryzacji miasta objął ewaluację przestrzeni publicznych oraz ocenę bezpieczeństwa przestrzeni miejskiej. W części tej (przegląd metod) przybliżono także zagadnienie waloryzacji inwestycyjnej. 
Definicję przestrzeni mieszkaniowej zaczerpnięto z publikacji L. Groeger (2013). W pracy tej podjęto się przeglądu oraz usystematyzowania zagadnień definicyjnych odnoszących się do rozumienia zakresu pojęciowego terminów środowisko mieszkaniowe i przestrzeń mieszkaniowa z uwzględnieniem różnych perspektyw naukowych, a także klasyfikacji przestrzeni. W efekcie autorka stworzyła własną definicję tego terminu wyraźnie nawiązującą do najogólniejszych i bezwzględnie przynależnych temu zagadnieniu cech. Przestrzeń mieszkaniowa została zdefiniowana jako „część przestrzeni (geograficznej), pełniąca realnie lub potencjalnie funkcje mieszkaniowe, zagospodarowana na cele mieszkaniowe, postrzegana przez ludność jako miejsce zamieszkania”. Przestrzeń mieszkaniową określono jako prywatną - odnoszącą się do samego mieszkania oraz publiczną - ogólnie dostępną.

A. Suliborski (1976) już w latach 70-tych, analizując strukturę środowiska mieszkaniowego wyróżnił cztery jego strefy: mieszkanie, budynek mieszkalny, teren otaczający budynek mieszkalny oraz przestrzeń położoną poza granicami nieruchomości, z którą człowiek pozostaje w bezpośrednim kontakcie z racji zamieszkiwania. Dwie pierwsze strefy określił wewnętrznym środowiskiem mieszkaniowym, natomiast dwie kolejne zewnętrznym środowiskiem mieszkaniowym. Strefy te różnią się miedzy sobą jednorodnością treści, znamiennością formy, rozległością przestrzenną oraz funkcją. W kolejnych latach architekci, urbaniści i geografowie analizując przestrzeń miejską, a w niej zawartą przestrzeń mieszkaniową stosowali najczęściej klasyfikacje oparte na dostępności nawiązując do tego podziału, rozróżniając tym samym przestrzeń prywatną, którą można odnosić do wewnętrznego środowiska mieszkaniowego oraz przestrzeń publiczną utożsamianą z zewnętrznym środowiskiem mieszkaniowym ${ }^{3}$ (Chmielewski 2000; Kaczmarek 1996).

Na rolę zagospodarowania publicznych przestrzeni mieszkaniowych w podnoszeniu ich jakości już w latach 70. zwracał uwagę duński architekt J. Gehl (2009). Obecnie w Polsce kwestie dotyczące, jakości i kształtowania przestrzeni publicznych zyskały na znaczeniu. Przestrzeń ta daje możliwość interakcji społecznych, przyczynia się do więzi sąsiedzkich, daje poczucie satysfakcji i bezpieczeństwa (Bać 2004; Bonenberg 2008; Strumiłło 2010). Dobrej jakości przestrzeń publiczna pełni funkcję promocyjną dla danego obszaru i przyczynia się do jego rozwoju. Dlatego jednym z kluczowych problemów związanych z oceną współczesnej przestrzeni mieszkaniowej jest zdefiniowanie kryteriów wartościujących jej jakość użytkową na aktualnym poziomie rozwoju. Mając przy tym na uwadze,

${ }^{3}$ Dla rozróżnienia zakresu znaczeniowego pojęć środowiska mieszkaniowego i przestrzeni mieszkaniowej fundamentalne znaczenie ma stwierdzenie teoretyka architektury Ch. Norberga-Schulza (2000), że środowisko jest dane człowiekowi, a przestrzeń sam kształtuje. 
iż wspomniana przestrzeń należy do elementarnych potrzeb człowieka, zagadnienie to można uznać za fundamentalnie ważne z punku widzenia kształtowania przyjaznych ludziom struktur osiedlowych.

Wskazane ujęcie problemu wynika bezpośrednio z systemowej struktury miasta, składającej się z dwóch autonomicznych podsystemów - urbanistycznego i społecznego, które są ze sobą organicznie powiązane i współdziałają na zasadzie sprzężeń zwrotnych (Wallis 1990).

W artykule podjęto się zaproponowania zmodyfikowanej metody audytu miejskiego, obejmującej system urbanistyczny i społeczny, do zastosowania w waloryzacji publicznej przestrzeni osiedli mieszkaniowych. Weryfikację metody jak i jej modyfikacje, dostosowane do celu badań, opracowano na podstawie analiz przeprowadzonych na osiedlu Wyzwolenia w Piotrkowie Trybunalskim oraz badań ankietowych z jego mieszkańcami realizowanych na potrzeby pracy magisterskiej K. Lasek (2021) „Waloryzacja przestrzeni mieszkaniowej na terenie osiedla Wyzwolenia w Piotrkowie Trybunalskim”.

\subsection{Metoda audytu miejskiego}

Szczegółowe informacje dotyczące idei oraz założeń metodologicznych audytu miejskiego przedstawione zostały w publikacji ,System monitorowania rewitalizacji” przygotowanej przez Instytutu Rozwoju Miast (2010).

Audyt miejski został zdefiniowany jako metoda ,zbierania, przetwarzania i wizualizacji danych przestrzennych, opisujących zjawiska i procesy społeczne, ekonomiczne oraz urbanistyczne, obserwowane w mieście" (System monitoringu rewitalizacji 2010: 29). Początek kształtowania się metody audytu miejskiego datuje się na lata 70 XX w., kiedy w Stanach Zjednoczonych zaczęto zwracać uwagę na konieczność monitorowania obszarów metropolitarnych. Funkcjonowały wówczas równolegle dwa terminy: Urban Audit oraz Urban Atlas. Drugie z wymienionych pojęć odnosiło się do publikowania serii map prezentujących wyniki określonych analiz w postaci atlasów. $\mathrm{Z}$ biegiem czasu zostały one przeniesione w sferę internetową i zaistniały jako powszechnie dzisiaj funkcjonujące geoportale. Formuła audytu miejskiego jest współcześnie wykorzystywana również w Europie, gdzie stanowi podstawę monitoringu obszarów zurbanizowanych poprzez dostarczanie zobrazowań satelitarnych oraz danych statystycznych o miastach gromadzonych w ramach programu Urban Audit. $Z$ uwagi na fundamentalne znaczenie tych danych Eurostat podjął w 2005 roku decyzję o konieczności cyklicznego i stałego ich zbierania (co 3 lata). Istotne jest przy tym, iż podejście europejskie zakłada koncentrację na kontekście regionalnym, z kolei podejście zaproponowane przez Instytut Rozwoju Miast ukierunkowane jest na poziom miejski (wewnątrzmiejski), a zaproponowana autorska modyfikacja dostosowuje metodę do skali i specyfiki osiedla mieszkaniowego. 
Zasadniczym celem audytu miejskiego jest identyfikacja obszarów kryzysowych w mieście na podstawie wyników wewnątrzmiejskich analiz zróżnicowania zjawisk społecznych, gospodarczych oraz przestrzennych. Analizy te prowadzi się w oparciu o kryteria obszarów kryzysowych, wyznaczone domyślnie na poziomie rządowym lub regionalnym. W szerszym kontekście, przy utrzymaniu cyklicznej realizacji badań, audyt umożliwia obserwację kierunków jakościowych przemian w przestrzeni określonego miasta. Jest także odpowiednią procedurą do wskazania zróżnicowania wewnątrzmiejskich terenów mieszkaniowych, w tym starych dzielnic śródmiejskich, powojennych osiedli mieszkaniowych (także osiedli przyzakładowych), obszarów zabudowy jednorodzinnej i mieszanej ze stosunkowo niewielkimi enklawami przemysłu i usługami, jak również zabudowy podmiejskiej i wiejskiej znajdującej się w granicach miast.

Istotnym zagadnieniem na wczesnym etapie opracowania audytu jest przyjęcie metody podziału na mniejsze jednostki przestrzenne. Zgodnie z wytycznymi Instytutu Rozwoju Miast wyróżnić można dwa warianty podejścia do realizacji audytu miejskiego z punktu widzenia jednostek przestrzennych, według których prowadzone są analizy. Pierwszy wariant zakłada wykorzystanie jednostek urbanistycznych ${ }^{4}$, natomiast drugi jednostek modularnych. Z uwagi na potrzebę uzyskania porównywalności wyników dane powinny być gromadzone w ramach jednostek przestrzennych o wysokim stopniu podobieństwa między sobą. W związku z tym konieczne jest, aby jednostki urbanistyczne odznaczały się możliwie wysoką jednorodnością funkcjonalną oraz stosunkowo wysoką homogenicznością pod względem morfologicznym i społecznym. Istotne jest przy tym, iż stanowią one naturalne jednostki do zbierania i przedstawiania informacji oraz podejmowania działań rewitalizacyjnych. $\mathrm{Z}$ drugiej jednak strony zarówno kształt jak i wielkość oraz położenie rzutują na losowość określonych cech. Wykorzystanie tego wariantu utrudnia również uwzględnienie oddziaływania pomiędzy sąsiednimi obszarami.

Zastosowanie jednostek modularnych zakłada wykorzystanie siatki kwadratów dających możliwość prezentacji ciągłości zjawisk w przestrzeni. Ukazując miejsca ich koncentracji pozwala wyznaczyć ogniska deprawacji przestrzeni miejskiej. Warto przy tym podkreślić, iż badane obszary tematyczne są zasadniczo podobne do uwzględnianych przy zastosowaniu jednostek urbanistycznych. Istotną właściwością tego wariantu jest niezależność względem podziałów administracyjnych ${ }^{5}$ oraz wyższa szczegółowość identyfikacji obszarów kryzysowych.

Audyt miejski ${ }^{6}$ sporządza się dla dwóch autonomicznych, a zarazem ściśle powiązanych i pozostających we wzajemnej interakcjach podsystemów:

${ }^{4} \mathrm{~W}$ przypadku jednostek urbanistycznych niezbędna jest generalizacja danych.

${ }^{5}$ Dane zbierane są wówczas w terenie.

${ }^{6}$ Procedurę realizacji audytu miejskiego opisano na przykładzie wariantu z zastosowaniem jednostek urbanistycznych. 
społeczno-gospodarczego oraz urbanistycznego. Przygotowaniem audytu miejskiego powinien być szczególnie zainteresowany samorząd lokalny z uwagi na możliwość szerszego wykorzystania badań, zwłaszcza w zakresie prowadzenia polityk miejskich oraz wyznaczania lokalizacji różnego rodzaju interwencji publicznych.

Audyt miejski w podsystemie społeczno-gospodarczym sporządza się z wykorzystaniem wskaźników z zakresu demografii (wiek, płeć, miejsce zamieszkania), bezpieczeństwa (typ przestępstwa, miejsce przestępstwa), edukacji (wykształcenie, płeć, miejsce zamieszkania), wykluczenia społecznego (typ otrzymanego zasiłku, wysokość otrzymanego zasiłku, miejsce zamieszkania) i gospodarki (numer PKD, miejsce prowadzenia działalności). Wymienione wyżej dane pozyskać można w Urzędzie Miasta, bazie PESEL, Policji, Powiatowym Urzędzie Pracy oraz Miejskim Ośrodku Pomocy Społecznej. Na ich podstawie możliwe jest przedstawienie rozmieszczenia ludności, przestępstw, przedsiębiorstw handlowych i usługowych, poziomu ubóstwa czy bezrobocia. Analizy w podsystemie społeczno-gospodarczym, z uwagi na charakter polityki miejskiej w odniesieniu do tych zjawisk, prowadzi się najczęściej z wykorzystaniem jednostek urbanistycznych. Podkreślić należy, iż istotnym elementem audytu powinna być ocena procesów i trendów w celu określenia tempa i kierunku rozwoju.

Audyt miejski w podsystemie urbanistycznym realizowany jest w celu oceny jakości (skali degradacji) techniczno-funkcjonalnej tkanki miejskiej, zwłaszcza obszarów zabudowy mieszkaniowej. Powinien on także uwzględniać zagadnienia związane z ochroną dziedzictwa kulturowego. Ocenie poddawane są następujące cechy tkanki miejskiej: a - budynki i budowle wymagające generalnego remontu, $\mathrm{b}$ - potrzeba termomodernizacji, c - substandardy architektoniczne nienadające się do modernizacji, d - uporządkowanie i uzupełnienie zabudowy, e - potrzeba budowy, uzupełnienia lub odnowy przestrzeni publicznych, terenów zieleni, rekreacji i wypoczynku, f - budowa lub poprawa jakości i standardu dróg i chodników lokalnych. Każdy z wymienionych elementów oceniany jest w skali czterostopniowej: 0 - brak problemu lub jego znaczenie nieistotne w skali jednostki urbanistycznej; 1 - występowanie problemu (dotyczące do 10\% obszaru/substancji); 2 - nasilenie problemu (dotyczące od 10\% do 50\% obszaru/substancji); 3 - szczególne nasilenie problemu (dotyczące powyżej 50\% obszaru/substancji). Dane do analiz pozyskuje się w ramach inwentaryzacji urbanistycznej.

W odniesieniu do dziedzictwa kulturowego sporządza się mapę przedstawiającą obiekty i obszary objęte ochroną konserwatorską, w tym: obiekty o najwyższej wartości kulturowej wpisane do rejestru zabytków, prowadzonego przez Wojewódzkiego Konserwatora Zabytków; obiekty posiadające znaczne wartości kulturowe, wpisane do gminnej ewidencji zabytków; strefy pełnej ochrony konserwatorskiej; strefy ochrony konserwatorskiej; strefy ochrony krajobrazu; strefy ochrony archeologicznej, strefy ochrony ekspozycji; strefy ścisłej ochrony 
archeologicznej; strefy obserwacji archeologicznej. Na podstawie wykonanej inwentaryzacji przeprowadza się typologię jednostek urbanistycznych według jakości i znaczenia dziedzictwa kulturowego. W ramach typologii wyróżnia się cztery stopnie jego koncentracji: 0 - nie występują; 1 - pojedyncze obiekty lub obszar objęty ochroną; 2 - koncentracja obiektów wpisanych do gminnej ewidencji, pojedyncze bardzo wartościowe obiekty; 3 - koncentracja obiektów o najwyższej wartości kulturowej na liście Wojewódzkiego Konserwatora Zabytków.

Oprócz wskazanych wyższej zasadniczych składników audytu miejskiego wyróżnić można także wskaźniki uzupełniające, uwzględniające ocenę i identyfikację znaczenia jednostek urbanistycznych w oparciu o typologię jednostek urbanistycznych według czterech klas obszarów: zabudowy jednorodzinnej; zabudowy mieszanej jednorodzinnej i wielorodzinnej; zabudowy wielorodzinnej oraz pełniących funkcje ponadlokalne; zabudowy centralnej i śródmiejskiej, pełniącej funkcje ponadlokalne i ponadmiejskie. Elementem uzupełniającym powinna być również ocena dostępności ${ }^{7}$ do podstawowych usług: szkół podstawowych, aptek, przystanków komunikacji publicznej, ośrodków podstawowej opieki zdrowotnej.

Instytut Rozwoju Miast w ramach kompleksowej realizacji audytu na potrzeby polityki miejskiej proponuje także inwentaryzacje terenów poprzemysłowych i zdegradowanych poza obszarami mieszkalnictwa. W tym celu obszary klasyfikowane są pod względem zagrożenia, jakie stanowią dla środowiska naturalnego i ludzi, a także w kontekście wymaganej interwencji. Za tworzenie bazy danych o terenach zdegradowanych powinny odpowiadać urzędy marszałkowskie ${ }^{8}$.

$\mathrm{Na}$ podstawie informacji zgromadzonych w układzie jednostek urbanistycznych należy wskazać obszary szczególnie zagrożone deprawacją społeczną, gospodarczą i urbanistyczną. W następstwie tego, w oparciu o określone graniczne wartości wskaźników (kryteria), wyznacza się obszary kryzysowe. Zakłada się przy tym opracowanie dwóch syntetycznych wskaźników kryzysowych dla jednostek urbanistycznych - osobno dla podsystemu społeczno-gospodarczego oraz dla podsystemu urbanistycznego. Do syntetycznej oceny natężenia zjawisk kryzysowych w podsystemie społecznym wykorzystuje się przyjęty w ramach analiz zbiór wskaźników ${ }^{9}$ ocenianych w odniesieniu do średniej dla miasta (jeżeli dany wskaźnik jest niższy od średniej dla miasta przyznaje się -1 (minus jeden) punkt, natomiast jeżeli dany wskaźnik jest wyższy od średniej dla miasta przyznaje się +1 (plus jeden) punkt. Po zsumowaniu ocen dla poszczególnych jednostek według wyróżnionych wskaźników uzyskuje się natężenie kryzysu w podsystemie

\footnotetext{
${ }^{7} \mathrm{~W}$ ramach metody oceny dostępności wykorzystuje się ekwidystanty.

${ }^{8}$ Przyjmuje się także, iż mogą to być Regionalne Obserwatoria Rozwoju Terytorialnego - ROPR.

${ }^{9} \mathrm{~W}$ opracowaniu przygotowanym przez Instytut Rozwoju Miast przyjęto zespół siedmiu wskaźników.
} 
społecznym. Analogiczną ocenę przeprowadza się dla podsystemu urbanistycznego w oparciu o wyniki opisanej wcześniej inwentaryzacji.

W oparciu o omówione wyżej wskaźniki cząstkowe (dla podsystemu społecznego i urbanistycznego) należy wykonać czteropolową typologię uwzględniającą obszary następujących klas: brak kryzysu; kryzys dotyczy podsystemu urbanistycznego; kryzys dotyczy podsystemu społeczno-gospodarczego; kryzys dotyczy podsystemu społeczno-gospodarczego i urbanistycznego.

Na potrzebę dostosowania metody audytu miejskiego do skali mniejszych jednostek przestrzennych oraz ich specyfiki zwróciła w swoich publikacjach uwagę W. Dragan. Metoda audytu miejskiego została tam wykorzystana do oceny jakości zagospodarowania dzielnicy staromiejskiej Mysłowic (Dragan 2015a) oraz dawnego osiedla kolejowego Sosnowiec Maczki (Dragan 2015b). Autorka ograniczyła się do zbadania podsystemu urbanistycznego przyjmując ulice jako jednostki analizy. Przyjęcie ulic jako jednostek urbanistycznych wymagało uwzględnienia ich długości, która z uwagi na możliwość występowania różnej liczby obiektów podlegających ocenie, może wpływać na zaburzenie wyników analiz. Powinno się zatem dążyć do osiągnięcia możliwie podobnych odcinków ulic posiadających zbliżoną liczbę obiektów. W pracy przestawiony został również schemat procedury badawczej wpisanej w realizację audytu miejskiego, w ramach której wyróżniono trzy zasadnicze fazy: przygotowania, realizacji oraz opracowania i analiz. W ramach pierwszej nich dokonuje się analizy archiwalnych materiałów kartograficznych, w celu doboru obszaru badań. Następnie należy podzielić wybrany obszar na tereny funkcjonalne ${ }^{10}$ oraz wydzielić obiekty zabytkowe. Na fazę drugą (realizacji) składają się badania terenowe, które obejmują wypełnienie matrycy danych (ocena ulic pod względem wyróżnionych cech) oraz dokumentacji fotograficznej. Wypełnienie matrycy danych, należącej do drugiej fazy audytu, polega na ocenie poszczególnych ulic wchodzących w skład osiedla pod względem wyróżnionych cech $\mathrm{w}$ skali od 0 do $3^{11}$. Na ostatnim etapie (opracowania $\mathrm{i}$ analiz) wykonuje się mapę degradacji przestrzeni oraz związane z tym analizy. Badania potwierdziły możliwość oraz zasadność odrębnego analizowania podsystemu urbanistycznego jako autonomicznego składnika przestrzeni miejskiej.

Wskazać można również alternatywne ujęcia audytu miejskiego, których zakres tematyczny odnosi się do różnych sfer zarządzania miastem. W nawiązaniu do celów może on dotyczyć: identyfikacji możliwości realizacji zamierzeń rozwojowych miast, w tym zbioru potencjałów, obejmującego wszystkie jego rozpoznane składniki, włącznie z elementami stanowiącymi wady miasta; zasobów

${ }^{10}$ Wyznaczenie terenów funkcjonalnych podyktowane jest koniecznością przygotowania odrębnych audytów dla poszczególnych rodzajów zabudowy.

${ }^{11}$ Cechy oraz skala ocen zostały zaczerpnięte z publikacji Instytutu rewitalizacji miasta (2010). 
występujących na jego obszarze, z uwzględnieniem cech ich dostępności, barier rozwoju miasta wynikających z istniejących uwarunkowań; celów podmiotów funkcjonujących na terenie miasta, posiadających niezależność w zakresie własnych decyzji rozwojowych, $\mathrm{z}$ uwzględnieniem zamierzenia istotnych dla miasta jednostek gospodarczych oraz zarządzających obiektami symbolicznymi (Czornik 2016). Audyt miejski może być także wykorzystywany do oceny ryzyka wynikającego z zaangażowania zasobów miejskich, jak również kontroli zgodności z celami użytkowników miasta oraz przygotowania wniosków stanowiących podłoże dla wyznaczenia kierunków rozwoju miasta (Czornik 2016).

\subsection{Waloryzacja przestrzeni osiedla Wyzwolenia w Piotrkowie Trybunalskim}

W pracy magisterskiej K. Lasek (2021) wykorzystał metodę audytu miejskiego do waloryzacji publicznej przestrzeni mieszkaniowej na terenie osiedla Wyzwolenia w Piotrkowie Trybunalskim. Podobnie jak w publikacjach W. Dragan (2015a, 2015b), w pracy magisterskiej K. Laska (2021) ograniczono się do zbadania podsystemu urbanistycznego, który analizowany był w układzie ulic i oceniany w skali czterostopniowej (włączając 0 - brak problemu) (wzorem podejścia W. Dragan 2015a, 2015b).

Schemat zastosowanej procedury badawczej wpisanej w realizację audytu miejskiego składa się z trzech zasadniczych faz: przygotowania, realizacji oraz opracowania i analiz. W ramach pierwszej nich dokonuje się analizy archiwalnych materiałów kartograficznych, w celu doboru obszaru badań. Następnie należy podzielić wybrany obszar na tereny funkcjonalne ${ }^{12}$ oraz wydzielić obiekty zabytkowe $^{13}$. Na fazę drugą (realizacji) składają się badania terenowe, które obejmują wypełnienie matrycy danych (ocena ulic pod względem wyróżnionych cech) oraz dokumentacji fotograficznej. Wypełnienie matrycy danych, należącej do drugiej fazy audytu, polega na ocenie poszczególnych ulic wchodzących w skład osiedla pod względem wyróżnionych cech w skali od 0 do $3^{14}$. Na ostatnim etapie (opracowania i analiz) wykonuje się mapę degradacji przestrzeni oraz związane z tym analizy. Badania potwierdziły możliwość oraz zasadność odrębnego analizowania podsystemu urbanistycznego jako autonomicznego składnika przestrzeni miejskiej.

${ }^{12}$ Wyznaczenie terenów funkcjonalnych podyktowane jest koniecznością przygotowania odrębnych audytów dla poszczególnych rodzajów zabudowy.

${ }^{13} \mathrm{~W}$ granicach obszaru badań nie zidentyfikowano żadnych obiektów zabytkowych.

${ }^{14}$ Cechy oraz skala ocen zostały zaczerpnięte z publikacji Instytutu rewitalizacji miasta (2010). 


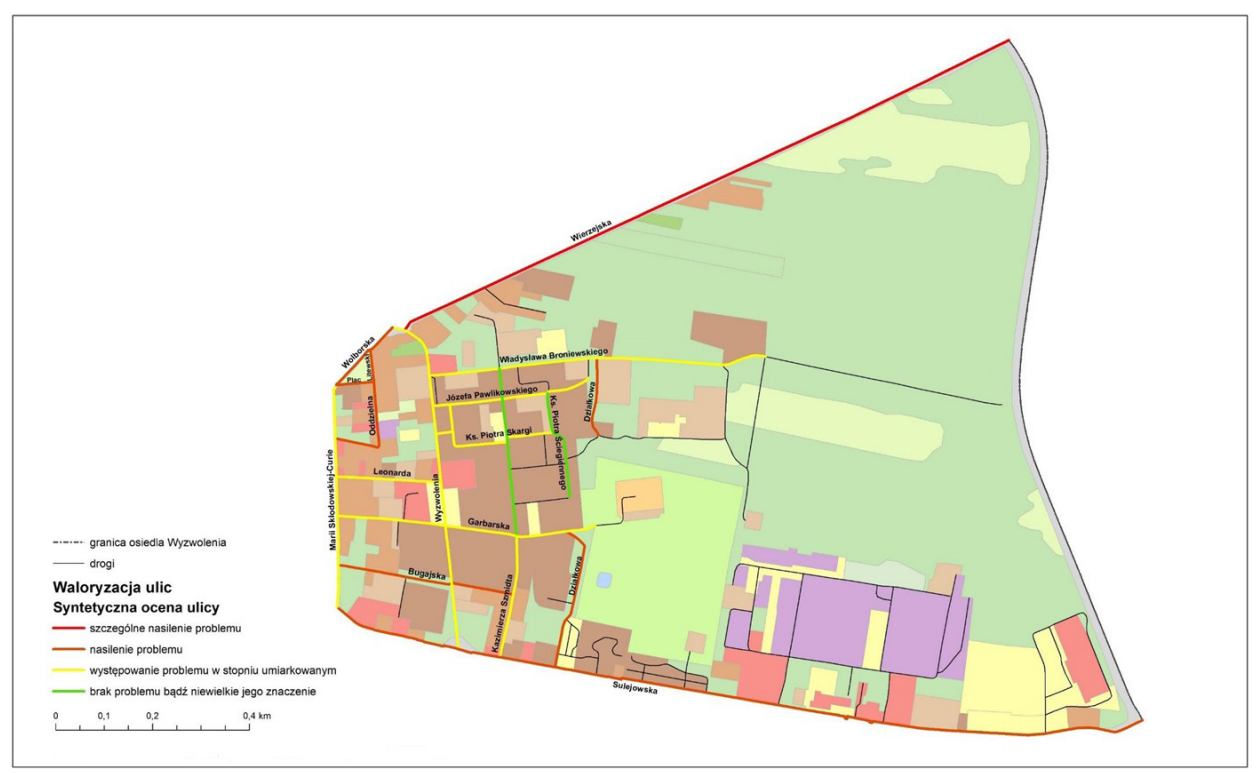

Ryc. 1. Syntetyczna ocena ulic osiedla Wyzwolenia

Źródło: opracowanie własne na podstawie danych udostępnionych przez Wojewódzki Ośrodek Dokumentacji Geodezyjnej oraz Kartograficznej w Łodzi oraz inwentaryzacji w terenie według stanu na 31.08.2020.

Przeprowadzone badanie pozwoliło stwierdzić stosunkowo wysokie zróżnicowanie jakości publicznej przestrzeni mieszkaniowej na badanym osiedlu (ryc. 1). Klasyfikacja ulic według stopni degradacji określonych elementów zagospodarowania objęła zarówno jednostki wyróżniające się brakiem problemów w zakresie analizowanych cech, jak również ulice charakteryzujące się umiarkowanym występowaniem problemów lub ich nasileniem, a zatem cechujące się znaczącym udziałem dysfunkcji w określonych obszarach tematycznych i wymagające złożonej renowacji obejmującej większe fragmenty przestrzeni, jak również jednostkę o szczególnym nasileniu problemów w zagospodarowaniu (stopnie krańcowe objęły najmniejszą liczbę ulic). Uzyskanie zróżnicowanego obrazu osiedla pod względem poziomu degradacji wyróżnionych cech pozwoliło stwierdzić zasadność stosowania metody audytu miejskiego jako narzędzia waloryzacji publicznej przestrzeni mieszkaniowej w kontekście formułowania polityki mieszkaniowej oraz działań rewitalizacyjnych, zauważając jednocześnie potrzebę jej wyższego dostosowania do badania współczesnych struktur mieszkaniowych, w tym osiedlowych

Metoda ta została uzupełniona społecznym postrzeganiem wspomnianej przestrzeni przez jej mieszkańców, uzyskanym w drodze realizacji sondażowego badania ankietowego, w ramach którego zastosowano próbę dostępnościową. 
Badanie przeprowadzone zostało w sposób bezpośredni oraz za pomocą łącza internetowego. Uzyskano łącznie 103 ankiety (51\% przebadanej społeczności stanowili mężczyźni, 49\% kobiety). Badaniu poddano jedynie osoby pełnoletnie. Najliczniejszą grupę stanowili respondenci w wieku od 50 do 64 lat (27 osób). Nieco mniej ankietowanych znalazło się w przedziale wiekowym od 40 do 49 lat (22 osoby). Ankieta objęła również 20 osób w wieku od 30 do 39 lat oraz 18 osób w wieku od 18 do 29 lat. Najstarsi przebadani mieszkańcy, będący w wieku powyżej 64 lat, stanowili najmniej liczbą grupę (16 osób) (ryc. 2).

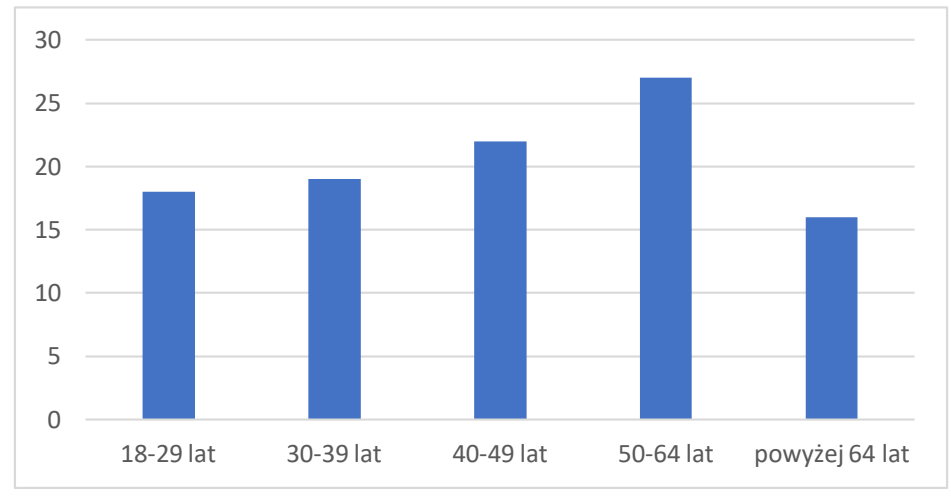

Ryc. 2. Struktura wiekowa respondentów

Źródło: opracowanie własne na podstawie wyników badania ankietowego przeprowadzonego w roku 2020 na grupie 103 mieszkańców osiedla Wyzwolenia.

Na podstawie zdobytych doświadczeń uznano, iż jedną z istotnych modyfikacji audytu miejskiego powinno być wydzielenie jakości dróg oraz jakości chodników jako osobnych kategorii zagospodarowania poddawanych ocenie w przyjętej skali punktowej. Analiza uzyskanych danych ankietowych pozwoliła zauważyć wyraźny rozdźwięk między tymi elementami w opinii mieszkańców przedmiotowego osiedla. W ujęciu bardziej szczegółowym stan techniczny dróg otrzymał najlepszą notę pod względem średniej wartości ocen, natomiast stan techniczny chodników znalazł się w grupie zmiennych o najmniejszym udziale najwyższej oceny punktowej (5) w strukturze ocen, będąc zarazem jedną z najniżej ocenionych cech pod względem oceny uśrednionej (ryc. 3). Różnica ta została uznana za podstawę wydzielenia wskazanych kategorii jako osobnych składników oceny audyty miejskiego, zwłaszcza, iż obserwacja osiedla Wyzwolenia pozwoliła stwierdzić wysoką częstość występowania takiej sytuacja w obrębie poszczególnych ulic. Wydzielenie wspomnianych cech uznano za zasadne także z uwagi na możliwość występowania błędów interpretacyjnych wynikających z nadawania jednej noty zmiennej łączącej dwa, często niejednakowe pod względem stopnia degradacji elementy zagospodarowania. 


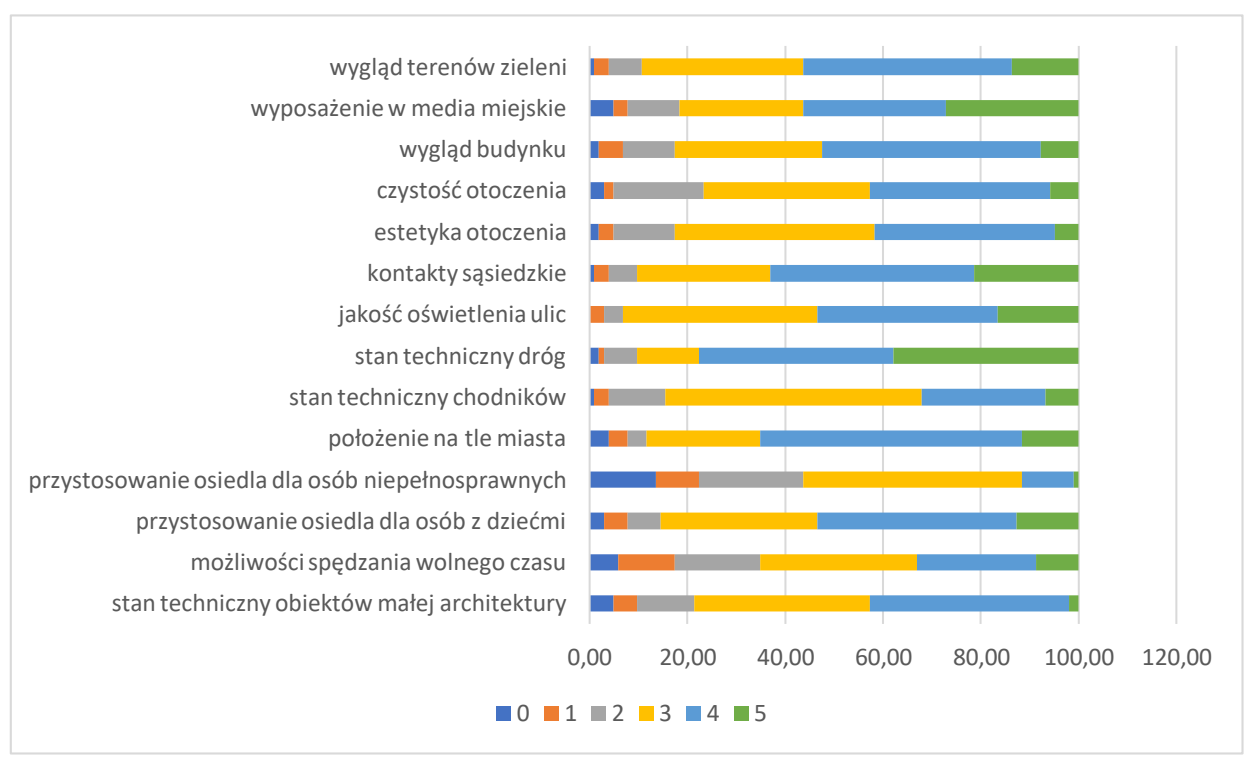

Ryc. 3. Struktura odpowiedzi na pytanie „Jak ocenia Pan/Pani osiedle Wyzwolenia pod względem niżej wymienionych cech w skali $0-5$ pkt ( 0 pkt. - nie wiem, 1 pkt - ocena bardzo niska, 2 pkt. - ocena niska, 3 pkt. - ocena średnia, 4 pkt. - ocena wysoka, 5 pkt. - ocena bardzo wysoka)?"

Źródło: opracowanie własne na podstawie wyników badania ankietowego przeprowadzonego w roku 2020 na grupie 103 mieszkańców osiedla Wyzwolenia.

Pod względem wartości uśrednionych wysoko ocenione zostały również kontakty sąsiedzkie. Należy mieć jednak na uwadze, iż ich średnia ocen wyniosła 3,74, co pozwala zauważyć widoczny spadek w stosunku do najwyżej ocenianej cechy (stanu technicznego dróg) (ryc. 4). Warto też zauważyć, iż wspomniane dwie zmienne odnoszą się do podstawowych kategorii sfery urbanistycznej i społecznej, przez co ich pozytywna ocena może w istotnym stopniu decydować o ogólnym postrzeganiu osiedla, co znalazło odzwierciedlenie w badaniu przeprowadzonym na społeczności osiedla Wyzwolenia w Piotrkowie Trybunalskim (Lasek 2021). 


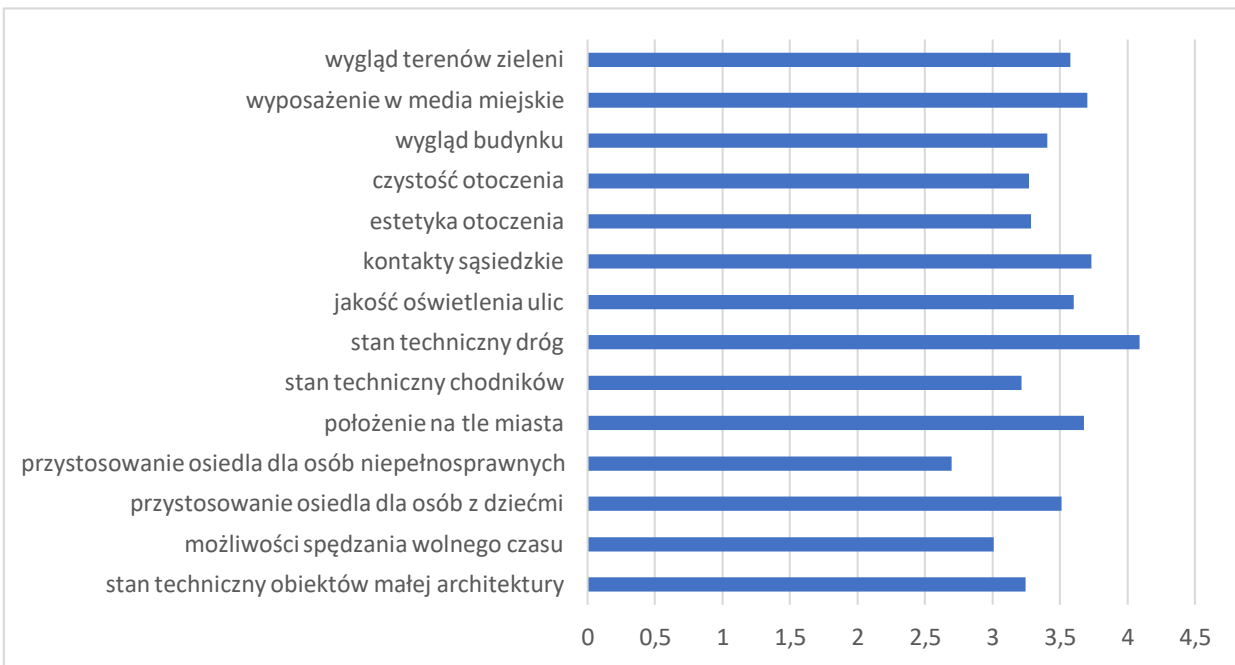

Ryc. 4. Średnie wartości cech zagospodarowania przestrzennego osiedla Wyzwolenia w Piotrkowie Trybunalskim

Źródło: opracowanie własne na podstawie wyników badania ankietowego przeprowadzonego w roku 2020 na grupie 103 mieszkańców osiedla Wyzwolenia.

W odniesieniu do proponowanych dodatkowych cech przewidzianych do uwzględnienia w ramach audytu miejskiego wyniki badania społecznego wykazały negatywną ocenę czystości otoczenia, stanu technicznego obiektów małej architektury oraz przystosowania osiedla do potrzeb osób niepełnosprawnych ${ }^{15}$. Znalazły się one także w grupie zmiennych o najmniejszym udziale najwyższej oceny punktowej (5) w ogólnej strukturze ocen ${ }^{16}$. Nakreślone wyżej właściwości postrzegania publicznej przestrzeni mieszkaniowej przez lokalną społeczność świadczą z jednej strony o niedoborze jakościowym i ilościowym wymienionych elementów, z drugiej natomiast o istotności tych składników zagospodarowania

${ }^{15} \mathrm{~W}$ ujęciu szczegółowym wyraźnie niskie noty uzyskały: wygląd budynku, estetyka otoczenia, czystość otoczenia, stan techniczny obiektów małej architektury, stan techniczny chodników oraz możliwości spędzania wolnego czasu, natomiast zdecydowanie najgorzej ocenione zostało przystosowanie osiedla do potrzeb osób niepełnosprawnych.

${ }^{16}$ Analiza wyników ankietowych pozwoliła stwierdzić, iż najwyższa ocena punktowa (5) posiadała najmniejszy udział w przypadku takich cech osiedla jak: przystosowanie osiedla dla osób niepełnosprawnych, stan techniczny obiektów małej architektury, czystość otoczenia, estetyka otoczenia, stan techniczny chodników, wygląd budynku możliwości spędzania wolnego czasu.

Należy jednak zaznaczyć, iż w przypadku stanu technicznego obiektów małej architektury szczególnie duży udział przypada ocenie punktowej 4 oraz 3, co pozwala stwierdzić, iż stosunkowo dużo osób ocenia tę cechę dobrze. 
dla mieszkańców osiedla. Są to jednocześnie elementy jednoznacznie przynależne sferze jakości publicznej przestrzeni mieszkaniowej, gdyż wpływają w sposób bezpośredni na komfort codziennego życia, przede wszystkim w kontekście przemieszczania się w lokalnej skali przestrzennej. Zgodnie z powyższym uznano za niezbędne wprowadzenie tych elementów do katalogu cech waloryzowanych drogą audytu. Warto też odnotować, iż najniższa nota punktowa (1) uzyskała największy udział $(11,65 \%)$ w strukturze ocen możliwości spędzania wolnego czasu, jednak uznano, iż cecha ta nie może podlegać obiektywnej i bezpośredniej ocenie w terenie.

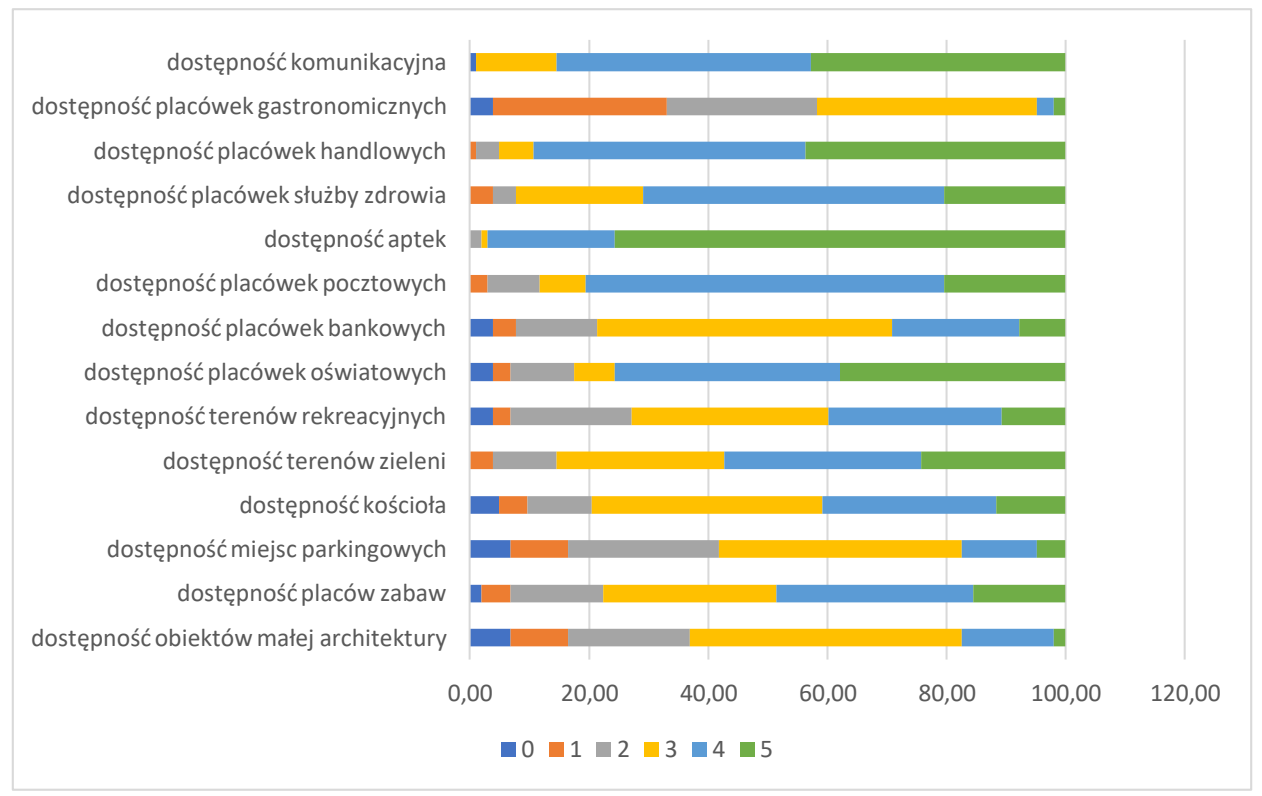

Ryc. 5. Struktura odpowiedzi na pytanie 8. Jak ocenia Pan/Pani osiedle Wyzwolenia pod względem niżej wymienionych cech w zakresie ich dostępności w skali $0-5$ pkt ( 0 pkt. - nie wiem, 1 pkt - ocena bardzo niska, 2 pkt. - ocena niska, 3 pkt. - ocena średnia, 4 pkt. - ocena wysoka, 5 pkt. - ocena bardzo wysoka)?"

Źródło: opracowanie własne na podstawie wyników badania ankietowego przeprowadzonego w roku 2020 na grupie 103 mieszkańców osiedla Wyzwolenia.

Zaproponowany katalog zmiennych uwzględnionych przy badaniu przestrzeni mieszkaniowej z zastosowaniem audytu miejskiego obejmuje potrzebę utworzenia lub odnowy elementów małej architektury. Jest to jeden z kluczowych składników przestrzeni publicznych, odgrywający istotną rolę w zakresie integracji mieszkańców oraz $\mathrm{w}$ znacznym stopniu decydujący o przystosowaniu osiedla do potrzeb osób starszych oraz z ograniczonych zdolnościach ruchowych. 
W badaniu ankietowym przeprowadzonym na społeczności osiedla Wyzwolenia, wraz z dostępnością placówek gastronomicznych i miejsc parkingowych, dostępność wspomnianych obiektów charakteryzowała się wysokim udziałem najniższych ocen punktowych (ryc. 5) oraz najgorszą pozycją pod względem średniej oceny (ryc. 6).

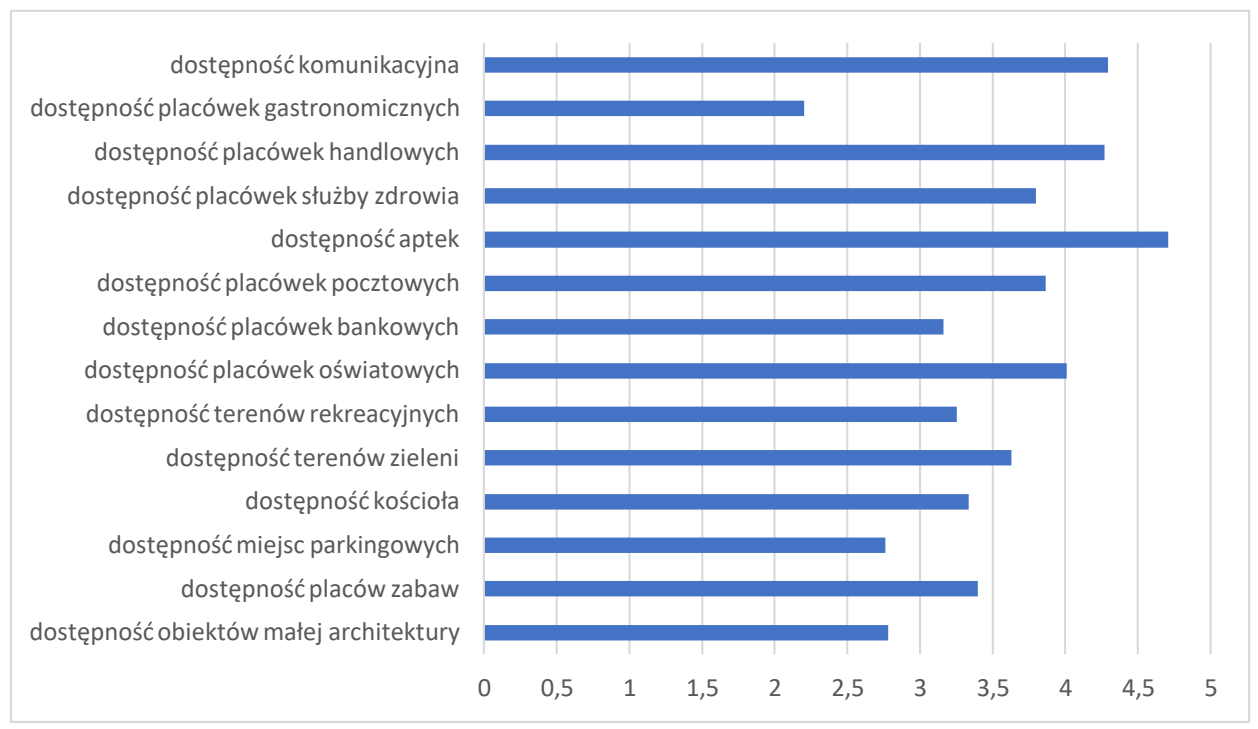

Ryc. 6. Średnie wartości dostępności określonych elementów zagospodarowania przestrzennego osiedla Wyzwolenia w Piotrkowie Trybunalskim

Źródło: opracowanie własne na podstawie wyników badania ankietowego przeprowadzonego w roku 2020 na grupie 103 mieszkańców osiedla Wyzwolenia.

Konieczność wprowadzenia wskazanej cechy wynikała zatem z wyraźnie niskiej oceny zarówno stanu jak i dostępności wspomnianych elementów. Warto też odnotować, iż dla kategorii tej właściwy był stosunkowo wysoki udział najsłabszych ocen punktowych (ryc. 5). Świadczy to o wysokim znaczeniu tego rodzaju składników zagospodarowania dla mieszkańców osiedla, zwłaszcza dla komfortu życia osób starszych. Należy przy tym zaznaczyć, iż wybór dodatkowych zmiennych audytu miejskiego podyktowany był możliwością jednoznacznej weryfikacji oraz oceny, przez co część z nich odrzucona została w ramach selekcji opartej na wskazanych warunkach. Uwzględniano również istotność danej cechy zagospodarowania z punktu widzenia jego przynależności do kategorii publicznej przestrzeni mieszkaniowej.

Za istotny element zagospodarowania, konieczny do uwzględnienia w audycie miejskim uznano także tereny zieleni, których znaczenie dla ludności zamieszkującej określone struktury mieszkaniowe jest niezaprzeczalne, zarówno z punktu 
widzenia potrzeb estetycznych i wypoczynkowych mieszkańców jak również kształtowania zrównoważonego środowiska życia. Mieszkańcy badanej społeczności zauważali istotne braki w zakresie walorów przyrodniczych $(29,13 \%)$, nadając im jednocześnie, w sposób pośredni, istotną wartość (ryc. 7). Włączenie wskazanej cechy znajduje zatem uzasadnienie także w społecznym postrzeganiu publicznej przestrzeni mieszkaniowej. Warto też odnotować, iż w opinii mieszkańców osiedla Wyzwolenia na temat deficytowych stref jego zagospodarowania respondenci wskazywali zdecydowanie najczęściej na walory kulturowe (aż 74,46\% ankietowanych wybrało tę odpowiedź), jednak ogólne właściwości związane $\mathrm{z}$ ich występowaniem $\mathrm{w}$ granicach struktur mieszkaniowych, w tym osiedlowych, a także ich związek relacyjny z przestrzenią mieszkaniową na płaszczyźnie integralności i przynależności nie pozwoliły na ich uwzględnienie.

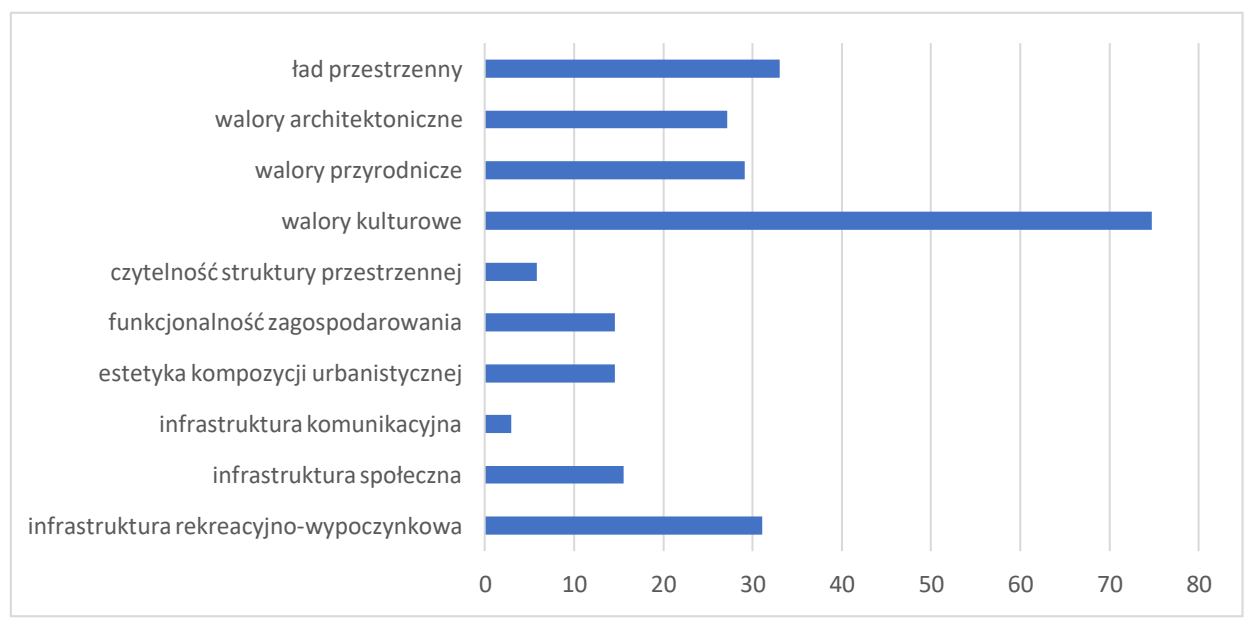

Ryc. 7. Struktura odpowiedzi na pytanie „W jakich sferach zagospodarowania osiedla zauważa Pan/Pani największe braki (proszę zaznaczyć maksymalnie trzy odpowiedzi)?” Źródło: opracowanie własne na podstawie wyników badania ankietowego przeprowadzonego w roku 2020 na grupie 103 mieszkańców osiedla Wyzwolenia.

Stwierdzono, iż zaproponowany dodatkowy zespół cech przewidzianych do uwzględniania w ramach realizacji audytu miejskiego dla obszarów mieszkaniowych odznacza się silną przynależnością dla kategorii publicznej przestrzeni mieszkaniowej stanowiąc zarazem dopełnienie katalogu przedstawionego przez Instytut Rozwoju Miast. Zasadniczą ich właściwością jest podporządkowanie potrzebom codziennego życia, w tym komfortu przemieszczania się i zaspokajania potrzeb estetycznych (w kontekście funkcjonowania w ramach przyjaznych struktur mieszkaniowych), a także włączenia do treści audytu potrzeb osób niepełnosprawnych, w tym osób o ograniczonych zdolnościach ruchowych. 


\subsection{Wnioski i rekomendacje do stosowania modyfikowanej metody audytu miejskiego do waloryzacji przestrzeni mieszkaniowej osiedla mieszkaniowego}

Zasadniczym celem audytu miejskiego w odniesieniu do badania przestrzeni mieszkaniowej jest jej ocena pod kątem wyróżnionych cech w przyjętej skali punktowej, w celu określenia stopnia nasilenia problemów w zagospodarowaniu poszczególnych ulic, których identyfikacja umożliwia wskazanie tych, które charakteryzują się najwyższym stopniem nasilenia problemów w sferze urbanistyczno-architektonicznej (a zatem wymagających interwencji w pierwszej kolejności) oraz, w zależności od założonych celów społecznych, dając tym samym podstawy do wyznaczenia kierunków zmian w zagospodarowaniu.

Analizując przydatność audytu miejskiego do oceny określonych obszarów publicznej przestrzeni mieszkaniowej za pośrednictwem waloryzacji istniejącego zagospodarowania należy stwierdzić, iż pozwala on na weryfikację kluczowych oraz nieco uogólnionych elementów należących do przedmiotowej kategorii, nie wyczerpując zarazem w pełni ich katalogu. Podstawową zaletą audytu jest jego prostota $\mathrm{w}$ warstwie proceduralnej oraz analitycznej (nieskomplikowana punktacja, możliwość obliczania wartości średnich, wyniki zobrazowane przestrzennie na mapach) dająca możliwość szerokiego stosowania, szczególnie przez samorządy lokalne, także w kontekście niskich kosztów realizacji takich badań. Analizy podsystemów urbanistycznego i społecznego w obszarze mieszkalnictwa prowadzi się najczęściej przy wykorzystaniu jednostek urbanistycznych. Korzystnym podejściem jest w szczególności realizacja audytu w układzie ulic. Daje to możliwość odniesienia wyników do zakodowanych w świadomości mieszkańców jednostek referencyjnych oraz określenie rekomendacji w ramach jednoznacznie określonych, również w sensie administracyjnym, przestrzeni miasta. Badania przeprowadzone $\mathrm{w}$ ramach pracy magisterskiej pozwoliły również wskazać na istotną rolę badania społecznego ${ }^{17}$ jako uzupełniania dla wyników audytu sporządzonego dla podsystemu urbanistycznego. Jest ono zarazem formą uwzględnienia partycypacji społecznej w kształtowaniu wytycznych do gospodarowania przestrzenią mieszkaniową. Należy też zaznaczyć, iż w opracowaniu skupiono się na badaniu publicznej przestrzeni mieszkaniowej, jednak w zależności od założonych celów waloryzacja może zostać uzupełniona o ocenę prywatnej przestrzeni mieszkaniowej jako równoważnej składowej ogólnej kategorii badanej przestrzeni.

Zestawienie uzyskanych w ten sposób danych (drogą audytu miejskiego oraz badania ankietowego), poprzez skonfrontowanie ujęcia możliwie obiektywnego z subiektywnym, pozwala otrzymać pełniejszy obraz jakości przestrzeni

\footnotetext{
${ }^{17}$ Badanie to powinno być również przeprowadzane w układzie ulic.
} 
mieszkaniowej. Wyznaczanie działań interwencyjnych w oparciu o te dwa spojrzenia rzutować powinno na wieloaspektową odnowę przestrzeni mieszkaniowej.

Zgodnie z przedstawionym wcześniej opisem realizacja audytu składa się $\mathrm{z}$ trzech zasadniczych faz:

1. Przygotowania

2. Realizacji

3. Opracowania i analiz

Doświadczenia zdobyte $\mathrm{w}$ ramach realizacji audytu, a także analizy postrzegania przestrzeni mieszkaniowej osiedla Wyzwolenia, rozpoznanego w drodze badania ankietowego przeprowadzonego na grupie 103 osób, pozwoliły sformułować określone modyfikacje w jeszcze wyższym stopniu przystosowujące wspomnianą metodę do badania przestrzeni mieszkaniowej. Przede wszystkim, w oparciu o autorskie analizy i spostrzeżenia, zaproponowano rozszerzenie listy badanych problemów dotyczących jakości przestrzeni mieszkaniowej. Warto zauważyć, iż potrzeba aktualizacji ocenianych właściwości zagospodarowania wynika m.in. ze zmian preferencji ludności związanych z miejscem zamieszkania w zależności od rozwoju społeczno-gospodarczego, przez co czynności w tym zakresie powinny być podejmowane regularnie. Włączenie do analiz dodatkowych cech zostało również podyktowane potrzebą uwzględnienia reprezentacji różnych sfer przestrzeni mieszkaniowej o podstawowym znaczeniu dla jakości życia w obrębie osiedla, których wzajemne relacje przestrzenne oraz odpowiednie nasycenie $\mathrm{w}$ granicach poszczególnych ulic (lub innych jednostek urbanistycznych), a zwłaszcza kompletność zbioru tych elementów, rzutuje na codzienny komfort życia. Zgodnie z przedstawionymi wcześniej autorskimi zmianami kata$\log$ zmiennych obejmuje 11 następujących cech:

- budynki wymagające generalnego remontu;

- potrzeba termomodernizacji;

- substandardy architektoniczne nie nadające się do modernizacji;

- uzupełnienie i uporządkowanie zabudowy;

- potrzeba budowy, uzupełnienia lub odnowy przestrzeni publicznych;

- budowa lub poprawa jakości i standardu dróg;

- budowa lub poprawa jakości i standardu chodników;

- potrzeba utworzenia, uzupełnienia lub odnowy terenów zieleni;

- potrzeba dostosowania przestrzeni dla osób starszych, niepełnosprawnych i dzieci;

- potrzeba utworzenia lub odnowy elementów małej architektury;

- potrzeba poprawy czystości otoczenia.

W ramach modyfikacji metody audytu miejskiego przyjęto także, iż każda cecha powinna być oceniana w skali $1-5$, co stanowi rozszerzenie i uszczegółowienie kategoryzacji punktowej w stosunku do założeń proponowanych przez 
Instytut Rozwoju Miast. W kształcie docelowym miałaby się ona składać z następujących stopni oceny:

0 - brak problemu $(0 \%)$,

1 - problem dotyczy do $10 \%$ badanej substancji (niewielkie nasilenie problemu),

2 - problem dotyczy od $10 \%$ do $25 \%$ badanej substancji (umiarkowane nasilenie problemu),

3 - problem dotyczy od $25 \%$ do $50 \%$ badanej substancji (wyraźne nasilenie problemu),

4 - problem dotyczy od 50\% do $75 \%$ badanej substancji (szczególne nasilenie problemu),

5 - problem dotyczy powyżej $75 \%$ badanej substancji (krytyczne nasilenie problemu).

Z przyjęciem tego podejścia wiąże się przede wszystkim wydłużenie realizacji audytu, jednak z punktu widzenia planowania szczegółowego harmonogramu działań interwencyjnych zmiana ta może odgrywać istotną rolę, pozostając w granicach wykonalności w kontekście bezpośredniej oceny stanu danej właściwości zagospodarowania w terenie. Uszczegółowienie kategoryzacji, zarówno w odniesieniu do zestawu badanych cech, jak również skali ocen służy dostosowaniu metody do skali osiedla mieszkaniowego i charakteru jego zagospodarowania, dając podstawę dla wieloaspektowej i kompleksowej oceny oraz racjonalnego planowana struktur mieszkaniowych. Skala czterostopniowa pozwala uzyskać zgeneralizowany obraz degradacji badanej przestrzeni, jednak w przypadku konieczności redystrybucji ograniczonych środków finansowych na działania skierowane ku odnowie jednostek najbardziej zdegradowanych (włączając w to potrzebę jednoznacznego określenia obszarów deficytowych), może on okazać się niewystarczający ze względu na umieszczenie większej liczny jednostek na tym samym szczeblu oceny, a tym samym utrudniać wskazanie w ich obrębie tych bardziej zdegradowanych (co w przypadku ograniczonych środków może mieć istotne znaczenie). Przyjęcie sześciostopniowej skali (włączając ocenę 0 - brak problemu), opartej na względnie podobnych zakresach procentowych przypisanych poszczególnych stopniom oceny, daje szansę uzyskania bardziej przejrzystego układu szczebli degradacji w obrębie badanego obszaru pozwalając na efektywniejsze zaplanowanie następujących po sobie działań rewitalizacyjnych/remontowych. Znajduje również uzasadnienie w charakterystyce wielkościowej większości osiedli mieszkaniowych, które ze względu na stosunkowo niewielkie rozmiary w skali miasta, pozwalają na wnikliwsze analizy w terenie.

Interpretacja wyników audytu miejskiego powinna uwzględniać analizę badanych cech osiedla rozpatrywanych w układzie ulic z wykorzystaniem dokumentacji fotograficznej oraz sporządzonych opracowań kartograficznych prezentujących każdą cechę osobno, a także analizę syntetycznej oceny przestrzeni mieszkaniowej przeprowadzoną w analogiczny sposób. Elementem wzbogacającym analizy 
powinna być tabela przedstawiająca sumaryczną długość oraz udział w ogólnej strukturze ulic o jednakowej syntetycznej ocenie badanej przestrzeni, a także analogiczne tabele sporządzone dla każdej z wyróżnionych cech. Ujęcie to wynika bezpośrednio z potrzeby uzyskania wielostronnych analiz stanowiących podłoże dla przyszłych decyzji interwencyjnych.

Przy badaniu przedmiotowych obszarów niezbędne jest zatem ścisłe i możliwe wyczerpujące zestawienie cech poddawanych ocenie celem kompleksowej analizy obecnego stanu oraz jednoznacznego wyznaczenia obszarów kryzysowych. Zakłada się, iż zaproponowany zestaw zmiennych uwzględnia najistotniejsze właściwości publicznej przestrzeni mieszkaniowej, nie wykraczając jednocześnie poza granice jego wykonalności w zakresie niezbędnego nakładu pracy i czasu. Jest to o tyle ważne, iż metoda ta powinna mieć powszechne zastosowanie w praktyce formułowania polityki miejskiej przez co odznaczać się powinna optymalnym nakładem szeroko pojętych kosztów. Niezwykle istotne jest również zachowanie cykliczności przeprowadzania audytu miejskiego, gdyż pozwala to uzyskać obraz przemian jakie dokonują się w określonej przestrzeni mieszkaniowej, dając tym samym podstawy do formułowania polityk miejskich w dłuższych horyzontach czasowych zogniskowanych na określonych aspektach działań interwencyjnych lub, szerzej, rozwojowych. Należy również podkreślić, iż nadrzędnym celem ogółu działań wpisanych w realizację audytu miejskiego powinno być przede wszystkim polepszenie jakości życia w obrębie określonych struktur mieszkaniowych.

\section{Literatura}

Bać Z., 2004, Psychologia organizacji przestrzeni środowiska mieszkaniowego. Habitaty 2003, Oficyna Wydawnicza Politechniki Wrocławskiej, Wrocław.

Bonenberg W., 2008, Przestrzeń publiczna w osiedlach mieszkaniowych, „Urbanista”, 12. Chmielewski J.M., 2001, Teoria urbanistyki w projektowaniu i planowaniu miast, Oficyna Wydawnicza Politechniki Warszawskiej, Warszawa.

Cieślak I. (red.), 2012, Wspótczesna waloryzacja przestrzeni zurbanizowanej, Wydawnictwo Uniwersytetu Wamińsko-Mazurskiego w Olsztynie, Olsztyn.

Czornik M., 2016, Cele audytu miejskiego, „Studia Ekonomiczne”, 270: 29-37, Wydawnictwo Uniwersytetu Ekonomicznego w Katowicach.

Dragan W., 2015a, Audyt miejski w procesie rewitalizacji dzielnic staromiejskich (na przykladzie Mystowic), „Studia Miejskie”, 17: 119-135.

Dragan W., 2015b, Zastosowanie audytu miejskiego do oceny zagospodarowania przestrzennego dawnego osiedla kolejowego na przykladzie Sosnowca Maczek, „Prace Geograficzne", 142: 77-88.

Gehl J., 2009, Życie między budynkami, Wydawnictwo RAM, Kraków.

Groeger L., 2013, Zróżnicowanie $i$ wartościowanie przestrzeni mieszkaniowej na przykładzie miast województwa tódzkiego, Wydawnictwo Uniwersytetu Łódzkiego, Łódź.

Groeger L., 2018, Środowisko mieszkaniowe a przestrzeń mieszkaniowa, „Space - Society - Economy", 26: 7-36. 
Janiszek M., Majorek A., 2017, Waloryzacja przestrzeni miejskiej na podstawie projektów zrealizowanych w ramach budżetu obywatelskiego, „Biuletyn KPZK”, 268: 167-185.

Jarczewski W., Jeżak J. (red.), 2010, System monitorowania rewitalizacji, t. 11, Instytut Rozwoju Miast w Krakowie, Kraków.

Kaczmarek S., 1996, Struktura przestrzenna warunków zamieszkania w Łodzi, Łódzkie Towarzystwo Naukowe, Łódź.

Kurek W., Mika M. (red.), 2008, Waloryzacja przestrzeni miejskiej Krakowa dla potrzeb turystyki. Raport końcowy, Instytut Geografii i Gospodarki Przestrzennej Uniwersytetu Jagiellońskiego, Kraków.

Lasek K., 2021, Waloryzacja przestrzeni mieszkaniowej na terenie osiedla Wyzwolenia w Piotrkowie Trybunalskim, praca magisterska napisana w Instytucie Zagospodarowania Środowiska i Polityki Przestrzennej Uniwersytetu Łódzkiego.

Sikora-Fernandez D., 2018, Deprywacja mieszkaniowa w Polsce na podstawie wybranych czynników, „Space - Society - Economy”, 26: 103-116.

Strumiłło K., 2010, Luksus na jaki każdy sobie zastużyt-mieszkać w nowoczesnym i pięknym otoczeniu na miare XXI wieku, „Architecturae et Artibus”, 2(2).

Suliborski A., 1976, Środowisko mieszkaniowe miasta jako przedmiot badań geografii osadnictwa, „Acta Universitatis Lodziensis”, Seria II, 7: 123-135.

Szul R., 1991, Przestrzeń. Gospodarka. Państwo, Wydawnictwa Programu CPBP, Warszawa.

Wallis A., 1990, Socjologia przestrzeni, Niezależna Oficyna Wydawnicza, Warszawa.

Włodarczyk M., 2014, Waloryzacja, wartościowanie i ochrona architektury 2 połowy XX wieku w Krakowie, Komisja Architektury XX wieku PKN ICOMOS. 